\title{
Fire Regimes and Resultant Forest Structure in the Native Año Nuevo Monterey Pine (Pinus radiata) Forest, California
}

\author{
SCOTT L. STEPHENS ${ }^{1}$ \\ Division of Ecosystem Science, Department of Environmental Science, Policy, and Management, \\ University of California, Berkeley 94720 \\ DOUGLAS D. PIIRTO \\ Natural Resources Management Department, \\ California Polytechnic State University, San Luis Obispo 93407 \\ AND \\ DOMENICO F. CARAMAGNO \\ Division of Ecosystem Science, Department of Environmental Science, Policy, and Management, \\ University of California, Berkeley 94720
}

\begin{abstract}
Native Monterey pine (Pinus radiata) forests occur in five populations on the west coast of North America. High severity fire has been reported to be the main disturbance agent that initiates seedling establishment for this species. To investigate the impacts of fire in this ecosystem, age structure and fire history data were collected from the native Año Nuevo Monterey pine forest near Santa Cruz, California. Stump cross-sections were removed from 10 randomly placed openings, and each was dated to determine tree age and fire history. Average mean fire return intervals were 11.2-20.1 y. Fifty-one percent of the Monterey pine trees in all openings regenerated within 5 y of three mixed severity fires. This was well below the predicted value of $75 \%$ that was based on the literature and life history characteristic of Monterey pine. A fire in 1948 produced the largest Monterey pine regeneration episode, and this fire was verified by written records. Monterey pine forests are multi-aged and have a great amount of spatial heterogeneity, attributes common in mixed severity fire regimes. Monterey pine has morphological characteristics of a fire evader and fire resistor and may be more appropriately classified in an intermediate category.
\end{abstract}

\section{INTRODUCTION}

Native Monterey pine (Pinus radiata D.Don) forests occur in five disjunct populations on the west coast of North America. Three are located in central-coastal California (Año Nuevo, Monterey, Cambria) and two on islands off the Baja California peninsula (Guadalupe and Cedros). Recent work has proposed that Monterey pine maintained a meta-population strategy throughout its history in the California region (Millar, 1999). Trees may have occurred in distinct coastal populations that were subject to repeated events of colonization, coalescence and local extirpation in responses to fluctuating climate (Millar, 1999).

Research on Monterey pine has focused on its ecological and timber properties in areas outside North America (Shelbourne et al., 1979; Burdon et al., 1997; Burdon et al., 2001; Reyes and Casal, 2001) and the trees' response to diseases and insects (Old et al., 1986; Storer and Wood, 1998; Gordon et al., 1998). No information exists on native Monterey pine stand age structure and the impact of fire on this ecosystem (White, 1999).

\footnotetext{
${ }^{1}$ Corresponding author: Telephone (510): 642-7304; FAX: (510) 643-5438; e-mail: stephens@nature. berkeley.edu
} 
Monterey pine is a closed-cone species and is intermediate in shade tolerance (Baker, 1949; McDonald and Laacke, 1990). Mature trees produce a canopy stored seed bank, and cones can remain attached to the tree for many years (Vogl et al., 1988). Maximum seed production begins at 15 or $20 \mathrm{y}$ of age if trees are open-grown (Cremer, 1992). Cones can open and close in response to changing humidity and temperature, but this releases little of the stored seed bank (McDonald and Laacke, 1990). Heat from high intensity fires can open and release the stored seed bank.

High severity fire has been reported to be the main disturbance agent that initiates seedling establishment (Fenton, 1951; Vogl et al., 1988; McDonald and Laacke, 1990; White, 1999) even though there is no research that has documented the role of fire in native Monterey pine ecosystems. Fire severity is commonly defined by the effects of fire on the dominant organisms of a particular ecosystem (Agee, 1998).

Fire regimes in Californian Monterey pine forests may contain a mixture of low, mixed (moderate) and high severity fires. Low severity fires consume ground and surface fuels, but cause little overstory mortality in most forests. Mixed severity fires cause some overstory tree mortality, but substantial numbers of trees in the larger size-classes survive these events (Agee, 1998). High severity fires commonly kill the majority of the trees in an area, and this allows for episodic regeneration if viable propagules survive and germinate (Turner et al., 1994; Turner et al., 1997; Agee, 1998).

Monterey pine has been classified as a fire evader primarily because of its canopy stored seed bank that is released after high severity fires (Fonda et al., 1998; Fonda, 2001). Characteristics of fire evaders include relatively thin bark, thin needle clusters that poorly protect meristems and aerial portions of the plant from thermal injuries and closed or serotinous cones (Fonda et al., 1998; Fonda, 2001).

There are no published studies that have estimated fire return intervals or investigated the effects of fire on forest structure in native Monterey pine forests (Greenlee and Langenheim, 1990; White, 1999; Fonda, 2001). One study (Fenton, 1951) measured seedling density after a New Zealand Monterey pine plantation was burned by a 1946 wildfire and an average of 897,000 Monterey pine seedlings $\mathrm{ha}^{-1}$ occurred. This study is probably not applicable to native forests because the area burned was a dense, 14-18 y old Monterey pine plantation.

The objective of this study was to investigate the fire history of a specific Monterey pine forest and determine how past fires have affected forest structure. This is the first study in California or Mexico to investigate this topic in pine dominated forests with closed or serotinous cones [including Monterey pine, bishop pine (Pinus muricata D. Don) and knobcone pine (P. attenuata Lemm.)]. A second objective was to determine if individual species responses are significantly different following mixed or high severity fires in this forest community.

\section{MeTHODS}

STUDY SITE

Age structure and fire history information was collected from Monterey pine forests at Swanton Pacific Ranch, located at $37^{\circ} 04^{\prime} 26.91^{\prime \prime} \mathrm{E}, 122^{\circ} 14^{\prime} 40.35^{\prime \prime} \mathrm{W}$, approximately $13 \mathrm{~km}$ north of Santa Cruz, California. Swanton Pacific Ranch encompasses 1280 ha and is contained in the Little Creek and Scott Creek watersheds (Fig. 1). Swanton Pacific Ranch includes portions of the native Año Nuevo Monterey pine forest, the most northern native population of this species. Trees in the study area include Monterey pine, Douglas fir [Pseudotsuga menziesii (Mirb.) Franco var. menziesii], coast live oak (Quercus agrifolia Nee) and tanoak (Lithocarpus densiflorus Rehder.). No large-scale tree harvesting occurred in these forests until a study was initiated in 2001 to investigate the resistance of Monterey pine to 


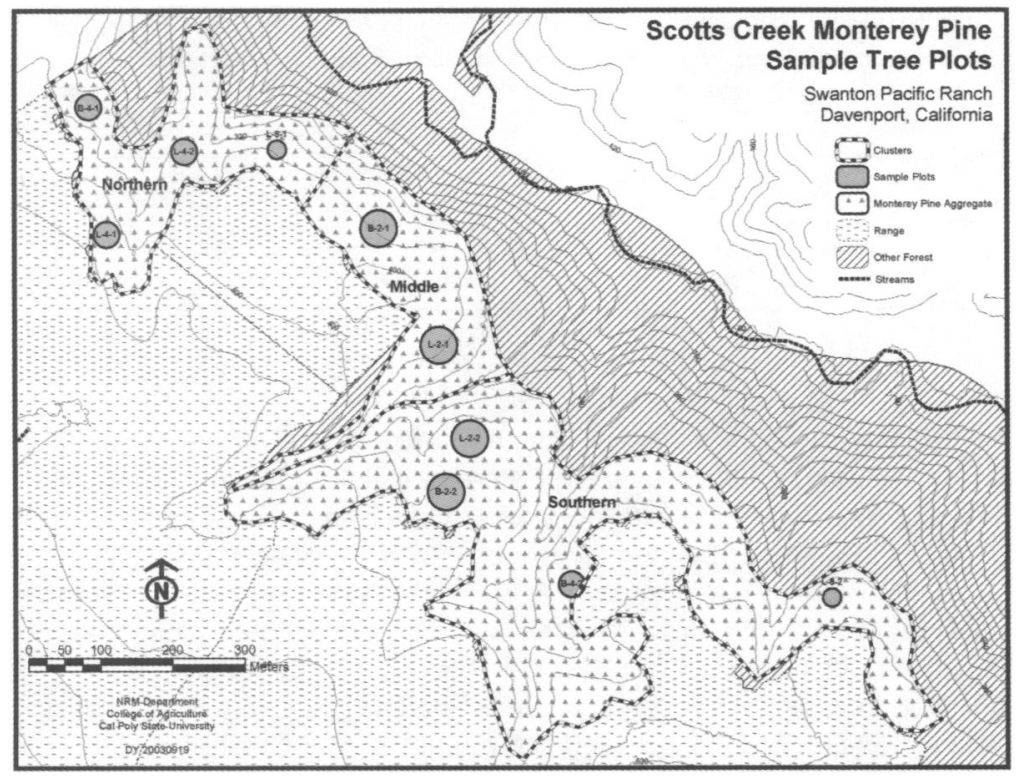

Fig. 1.-Location of the ten openings used to determine age structure and fire history in Monterey pine forests at Swanton Pacific Ranch, California

pitch canker disease (Fusarium moniliforme var. subglutinans). Some trees have been removed over the years for firewood production, but this has mostly impacted areas adjacent to grasslands because of easy access.

Understory species common in this area include coast live oak, bracken fern [Pteridium aquilinum L. (Kuhn)], poison-oak (Toxicodendron diversilobum E. Greene), coyote bush (Baccharis pilularis DC.), blue blossom (Ceanothus thyrsiflorus Eschsch.), California coffeeberry (Rhamnus californica Eschsch.), California blackberry (Rubus ursinus Cham. \& Schldl.), coast sagebrush (Artemisia californica Less.) and several grasses (Poaceae) (McDonald and Laacke, 1990).

During the prehistoric period, the Central California Ohlone Indians lived in the present area of Swanton Pacific Ranch. In 1843 the Mexican Governor of California granted this area to Ramon Rodriguez and Francisco Alviso, and the land was used primarily for farming and dairy cattle. These early land uses were concentrated in the grasslands and valleys of the area. From 1906-1923 the majority of the redwood [Sequoia sempervirens (D. Don) Endl.] and Douglas-fir forests were harvested to produce lumber to rebuild San Francisco after the 1906 earthquake; farming also continued during this period. In the 1940s the production of beef cattle intensified. Currently the ranch is California Polytechnic State University's field teaching and research property.

The climate at Swanton Pacific is Mediterranean, where it receives $79 \mathrm{~cm}$ of precipitation in an average year (Swanton records from 1956-1996). The soils of Monterey pine forest at Swanton Pacific are in the Ben Lomond-Catelli-Sur complex (Bowman and Estrada, 1980). These soils are well drained and were formed in residuum derived from sandstone or quartz diorite. Soil depths are approximately $100-180 \mathrm{~cm}$. Slopes within the experimental area varied from $8-30 \%$, aspects were mostly northern and the average elevation of the study area is approximately $390 \mathrm{~m}$ (Table 1). 
TABLE 1.-Forest opening characteristics in Monterey pine forests at Swanton Pacific Ranch, California

\begin{tabular}{|c|c|c|c|c|c|c|c|c|c|c|}
\hline & \multicolumn{4}{|c|}{ Northern cluster } & \multicolumn{2}{|c|}{ Middle cluster } & \multicolumn{4}{|c|}{ Southern cluster } \\
\hline & $\mathrm{L}-8-1$ & $\mathrm{~L}-4-1$ & B-4-1 & $\mathrm{L}-4-2$ & L-2-1 & B-2-1 & $\mathrm{L}-8-2$ & B-4-2 & B-2-2 & $\mathrm{L}-2-2$ \\
\hline Opening Size (ha) & 0.05 & 0.1 & 0.1 & 0.1 & 0.2 & 0.2 & 0.05 & 0.1 & 0.2 & 0.2 \\
\hline Elevation $(\mathrm{m})$ & 380 & 425 & 355 & 360 & 365 & 365 & 470 & 415 & 410 & 390 \\
\hline Slope $(\%)$ & 29 & 24 & 25 & 11 & 25 & 24 & 24 & 8 & 12 & 15 \\
\hline Aspect & $\mathrm{N}$ & $\mathrm{NE}$ & $\mathrm{N}$ & $\mathrm{N}$ & $\mathrm{E}$ & $\mathrm{N}-\mathrm{NE}$ & $\mathrm{N}$ & NW & $\mathrm{N}$ & $\mathrm{N}$ \\
\hline
\end{tabular}

\section{AGE STRUCTURE AND FIRE HISTORY}

Monterey pine forests at Swanton Pacific Ranch were originally delineated using a vegetation survey map. This map was digitized into a geographic information system (GIS) database and improved using the interpretation of black and white digital orthophotos. The interface between the Monterey pine forests and the grasslands and shrublands was clearly visible in the orthophotos. The boundary between the Monterey pine forests and the other forest types (redwood, Douglas-fir, coast live oak) was determined using a combination of orthophotos and field surveys.

Once the Monterey pine forest area was delineated, a $1 \mathrm{~m}$ grid was superimposed on this area using ARC/INFO GIS. Each grid cell had unique $\mathrm{x}$ and $\mathrm{y}$ coordinates, and the locations of a set of openings were randomly selected from the grid with the following constraints: (1) each location must be dominated by Monterey pine and maximum slope was limited to $30 \%$ to allow ground-based machinery to harvest the trees to create an openings and (2) each opening must have a $30 \mathrm{~m}$ buffer from an adjacent opening or the edge of the Monterey pine forest to reduce edge effects. If either of these constraints were violated, the selected grid point was rejected and a new grid location was randomly selected.

Openings sizes were $0.05,0.1$ or 0.2 ha and were randomly assigned to the grid points. Opening size was varied to accommodate a future study on the impacts of pitch canker disease on Monterey pine seedling growth. Trees in the openings were removed in 2001 using chainsaw felling and tractor yarding. The Monterey pine forests were divided into three areas (northern, middle and southern clusters) (Fig. 1), separated by approximately $800 \mathrm{~m}$, to allow analyzes to determine if there was heterogeneity in age structure or fire history in the sampled areas. Changes in topography (ridgelines and basins) assisted in the delineation of the clusters.

After the harvesting was completed, the tops of all stumps larger than $10 \mathrm{~cm}$ in diameter were removed using a chainsaw. Each stump cross-section was sanded and polished to a high sheen (400 grit) so that tree rings and fire scars could be distinguished. Stump height, diameter and species were recorded. To describe our forests, we calculated average basal area per ha, average number of trees per ha, average percent basal area by species and average percent stocking by species using the stump information collected from the openings.

Fire scars were identified on each stump cross-section by the characteristic disruption and healing patterns of radial tree-ring growth (McBride, 1983; Dieterich and Swetnam, 1984). The year of each fire and age of each tree was determined by cross-dating using standard dendrochronological techniques (Stokes and Smiley, 1977; Swetnam et al., 1985). The position within the ring in which a fire scar occurred was noted as EE (early earlywood), ME (middle earlywood), LE (late earlywood), LW (latewood), D (dormant) or U (undetermined) (Caprio and Swetnam, 1995) to serve as an estimate of the season of fire occurrence (Ahlstrand, 1980; Dieterich and Swetnam, 1984).

Composite fire chronologies were developed for the northern, middle and southern clusters independently, including all fires recorded in each site. Developing fire statistics 
using all fire scars was done because fire scars were relatively rare. For each cluster, we determined the mean, minimum and maximum fire return interval (FRI) over the period of record (Grissino-Mayer, 2001).

We estimate fire severity by assessing the amount of regeneration that followed past fires as an indicator of how fires affected the overstory tree canopy (Agee, 1998). A high severity fire was defined as one that initiated $>75 \%$ of the trees in all clusters (north, middle, south) within $5 \mathrm{y}$ of the event. A mixed severity fire was defined as one that initiated between $10-75 \%$ of the trees in all clusters within $5 \mathrm{y}$ of the event. A 5 y buffer was chosen because age was determined at stump height and stump heights varied. Furthermore, Monterey pine is intermediate in shade tolerance (Baker, 1949) and would grow at different rates depending on the local environment (differences in overstory canopy cover after fire could effect seedling growth). Monterey pine is a closed cone species (McDonald and Laacke, 1990), and it has been reported to be a fire evader (Fonda, 2001), so we hypothesized that $>75 \%$ of the Monterey pine trees in our forest would have regenerated as a result of high severity fires.

\section{INDIVIDUAL SPECIES RESPONSES TO HIGH AND MIXED SEVERITY FIRES}

Monterey pine was the most shade intolerant species in our forest. In contrast, coast live oak is shade tolerant and has increased in abundance in the absence of disturbance (White, 1999). With these differing physiologies, we hypothesized that these two species would respond differently to mixed and high severity fires. It was anticipated that Monterey pine would regenerate episodically after severe fire because of its relative shade intolerance and canopy stored seed bank. In contrast, coast live oak would not regenerate after such disturbances because it cannot protect its seed bank (acorns) from lethal temperatures during severe fires. Coast live oak should continue to recruit in the shaded understory once an overstory canopy had developed (White, 1999).

To assess statistical significance in recruitment for these two species, confidence limits for the number of trees recruited in the openings within $5 \mathrm{y}$ of mixed or high severity fires were calculated (Condit et al., 1995). We calculated confidence limits from binomial probabilities using the S-Plus statistical software package (Crawly, 2002). We calculated 95\% confidence limits by species for every mixed and high severity fire by searching for a population mean $R$ for which the binomial probability of observing $\mathrm{R}$ or less would be $<0.025$ as this was the upper confidence limit (Condit et al., 1995). The lower confidence limit was determined analogously.

\section{RESULTS}

We collected a total of 226 stump cross-sections from ten openings (Table 1). The pith date and fire history was obtained from 224 stump cross-sections. Two samples had excessive rotten wood and could not be analyzed. Additional openings were harvested in areas dominated by coast live oak to accommodate a future study on pitch canker disease dynamics, but they were not used in this analysis because Monterey pine was rare.

Average tree density and total basal area in the openings was 193 trees ha $^{-1}$ (SE 41.97) and $59.5 \mathrm{~m}^{2} \mathrm{ha}^{-1}$ (SE 7.94), respectively. Average stump height was $28.4 \mathrm{~cm}$ (range 19-43 cm). Monterey pine dominated the forests in the openings, contributing to $60 \%$ of average plot stocking (trees $\mathrm{ha}^{-1}$ ) and $75 \%$ of average plot basal area (Table 2). All stand characteristics were computed using data collected at stump height rather than at $1.4 \mathrm{~m}$ above the ground (diameter at breast height) where most siliviculture studies measure stand variables.

Cross-dating was successful for all conifer stump cross-sections (Monterey pine and Douglas-fir). Drought years in 1959-1961 and 1976-1977 assisted in cross-dating. Crossdating of the angiosperm samples (coast live oak and tanoak) was not possible because of complacent rings and extensive rays that spread through annual ring boundaries. Several 
TABLE 2.-Average basal area and tree density by species in the ten openings created at Swanton Pacific Ranch, California. Numbers in parentheses are SE

\begin{tabular}{lcrrr}
\hline \multicolumn{1}{c}{ Species } & Monterey pine & Coast live oak & Douglas-fir & Tanoak \\
\hline Basal area $\left(\mathrm{m}^{2} \mathrm{ha}^{-1}\right)$ & $44.8(6.47)$ & $9.48(2.63)$ & $4.93(2.09)$ & $0.25(0.02)$ \\
Tree density $\left(\right.$ trees $\left.\mathrm{ha}^{-1}\right)$ & $116.50(30.27)$ & $62.5(16.38)$ & $13.00(4.48)$ & $0.40(0.04)$ \\
\hline
\end{tabular}

wood stains were used to try to enhance the annual rings but they were not successful. The best method of sample preparation was producing a very high polish on the stump crosssections allowing us to count rings using a $20 \times$ microscope. Douglas-fir were the oldest trees sampled.

Twenty-five stumps (13 Monterey pine, 9 coast live oak, 3 Douglas-fir) contained 30 fire scars. Fires were recorded from 1893-1976, and the mean fire return interval for the northern, middle and southern clusters averaged from 11.4 to 20.1 y (Table 3 ). The period from the tree origination date to the first fire scar was not used in calculating mean fire return intervals. Intra-annual ring position of the scars was determined for $63 \%$ of the fire scars. Fire scars were mostly located at the ring boundary that would be associated with dormant season fires $(53 \%)$, fire scars in the late earlywood of the annual growth ring comprised $36 \%$ of all fire scars. Three mixed severity fires occurred from the late 1800 s to 2001 (1936, 1948 and 1957) (Table 4). No high severity fires were recorded.

Monterey pine and coast live oak responded differently after mixed severity fires. Fifty-one percent of Monterey pine trees in all openings germinated within $5 \mathrm{y}$ of three mixed severity fires $(1936,1948,1957)$, whereas only $16 \%$ of coast live oak was regenerated in the similar time period (Table 5). The percentage of Monterey pine regenerated after the mixed severity fires was significantly different from coast live oak in the northern, middle and southern clusters (Table 5). Recruitment statistics were not calculated for Douglas-fir and tanoak because they were rare.

\section{Discussion}

Complete stump cross-sections were necessary to distinguish between adjacent annual rings and rays on coast live oak and tanoak samples. Although the hardwood samples were

TABLE 3.-Fire history statistics from Monterey pine forests at Swanton Pacific Ranch, California. Monterey pine forests were divided into three areas (northern, middle and southern clusters) (Fig. 1), to allow analyzes to determine if there was heterogeneity in age structure or fire history

\begin{tabular}{lccc}
\hline \hline & Northern cluster & Middle cluster & Southern cluster \\
\hline Mean fire return interval (y) & 11.4 & 11.2 & 20.1 \\
Minimum fire return interval (y) & 4.0 & 4.0 & 6.0 \\
Maximum fire return interval (y) & 29.0 & 40.0 & 44.0 \\
Intra-ring fire scar position $^{1}(\%)$ & $50 \%$ dormant & $86 \%$ dormant & $25 \%$ dormant \\
& $25 \%$ latewood & $14 \%$ late earlywood & $75 \%$ late earlywood \\
& $25 \%$ late earlywood & & \\
Fire years from fire scars & $1919,1948,1957$, & $1896,1936,1943$, & $1893,1907,1951$, \\
& 1961,1976 & $1948,1952,1957$, & 1957,1973 \\
Total area of cluster (ha) & 6.0 & 1963 & 16.0 \\
\hline
\end{tabular}

\footnotetext{
${ }^{1}$ Position within the ring in which a fire scar occurred was noted as late earlywood, latewood or dormant to serve as an estimate of the season of fire occurrence
} 
TABLE 4.-Percent and total number of trees regenerated within 5 y after 3 mixed severity fires in Monterey pine forests at Swanton Pacific Ranch, California. Monterey pine forests were divided into three areas (northern, middle and southern clusters) (Fig. 1), to allow analyses to determine if there was heterogeneity in age structure or fire history. Older includes all trees with ages $>5$ y of the recorded fire year; younger includes all trees with ages $<$ the recorded fire year

\begin{tabular}{|c|c|c|c|c|c|c|c|c|c|}
\hline \multirow[b]{2}{*}{ Year } & \multicolumn{3}{|c|}{ Northern cluster } & \multicolumn{3}{|c|}{ Middle cluster } & \multicolumn{3}{|c|}{ Southern cluster } \\
\hline & Fire year & Older & Younger & Fire year & Older & Younger & Fire year & Older & Younger \\
\hline 1936 & $\begin{array}{l}\text { not } \\
\quad \text { recorded }\end{array}$ & n.a & n.a & $\begin{array}{l}18 \% \\
\quad \text { (9 Pira, } \\
5 \text { Quag) }\end{array}$ & $\begin{array}{l}27 \% \\
\quad \text { (2 Pira, } \\
16 \text { Quag, } \\
\text { 4 Psme) }\end{array}$ & $\begin{array}{l}55 \% \\
\text { (30 Pira, } \\
10 \text { Quag, } \\
2 \text { Lide) }\end{array}$ & $\begin{array}{l}\text { not } \\
\text { recorded }\end{array}$ & n.a & n.a \\
\hline 1948 & $\begin{array}{l}44 \% \\
\text { (33 Pira, } \\
5 \text { Quag, } \\
4 \text { Psme) }\end{array}$ & $\begin{array}{l}25 \% \\
\text { (13 Pira, } \\
10 \text { Quag, } \\
1 \text { Psme) }\end{array}$ & $\begin{array}{l}31 \% \\
\text { (19 Pira, } \\
10 \text { Quag, } \\
1 \text { Psme) }\end{array}$ & $\begin{array}{l}20 \% \\
\quad \text { (13 Pira, } \\
2 \text { Quag) }\end{array}$ & $\begin{array}{l}59 \% \\
\quad \text { (18 Pira, } \\
23 \text { Quag, } \\
\text { 4 Psme) }\end{array}$ & $\begin{array}{l}21 \% \\
\text { (10 Pira, } \\
6 \text { Quag, } \\
2 \text { Lide) }\end{array}$ & $\begin{array}{l}\text { not } \\
\text { recorded }\end{array}$ & n.a & n.a \\
\hline 1957 & $\begin{array}{l}8 \% \\
\text { (6 Pira, } \\
1 \text { Quag, } \\
1 \text { Psme) }\end{array}$ & $\begin{array}{l}83 \% \\
\quad \text { (53 Pira, } \\
21 \text { Quag, } \\
5 \text { Psme) }\end{array}$ & $\begin{array}{l}9 \% \\
\quad \text { (6 Pira, } \\
\quad 3 \text { Quag) }\end{array}$ & $\begin{array}{l}\text { not } \\
\text { recorded }\end{array}$ & n.a & n.a & $\begin{array}{l}28 \% \\
\quad \text { (12 Pira, } \\
1 \text { Psme) }\end{array}$ & $\begin{array}{l}29 \% \\
\quad \text { (6 Pira, } \\
6 \text { Quag, } \\
2 \text { Psme) }\end{array}$ & $\begin{array}{l}43 \% \\
\quad \text { (14 Pira, } \\
6 \text { Quag) }\end{array}$ \\
\hline
\end{tabular}

Pira $=$ Monterey pine, Quag $=$ coast live oak, Psme $=$ Douglas-fir, Lide $=$ tanoak, n.a $=$ not applicable 
TABLE 5.-Percent of trees regenerated within $5 \mathrm{y}$ of 3 mixed severity fires in Monterey pine forests at Swanton Pacific Ranch, California. Mean values in a column followed by the same letter are not significantly different at $\mathrm{P}<0.05$

\begin{tabular}{lcccc}
\hline \multicolumn{1}{c}{ Years } & Northern cluster & Middle cluster & Southern cluster & Average \\
\hline Trees regenerated $(\%)$ & 52 & 38 & 28 & 39 \\
Monterey pine & $60 \mathrm{a}$ & $54 \mathrm{a}$ & $38 \mathrm{a}$ & 51 \\
Coast live oak & $24 \mathrm{~b}$ & $23 \mathrm{~b}$ & $0 \mathrm{~b}$ & 16 \\
Douglas-fir & 83 & 0 & 33 & 44 \\
\hline
\end{tabular}

not cross-dated, we believe the use of full cross-sections with excellent sample preparation reduced the chances for error. Most fire scars $(72 \%)$ in this study were buried inside the tree stem and not recognizable from external tree characteristics (Stephens, 2001). Collection of fire scars samples from trees that only had visible injuries would have resulted in an incomplete fire record for this site.

Low severity fires were relatively common, especially from 1940 to 1970 (Figs. 2-4). Changes in land management at Swanton Pacific Ranch in the early 1940s probably contributed to the higher number of low severity fires. Beginning in the 1940s, the production of beef cattle became a priority of the ranch and burning was used to clear brush fields and maintain forage production. Since the Monterey pine forests at Swanton are adjacent to grasslands and shrublands (Fig. 1), many of the rangeland fires probably spread into the forest. Intentional burning to enhance forage production ended in the 1960s. This

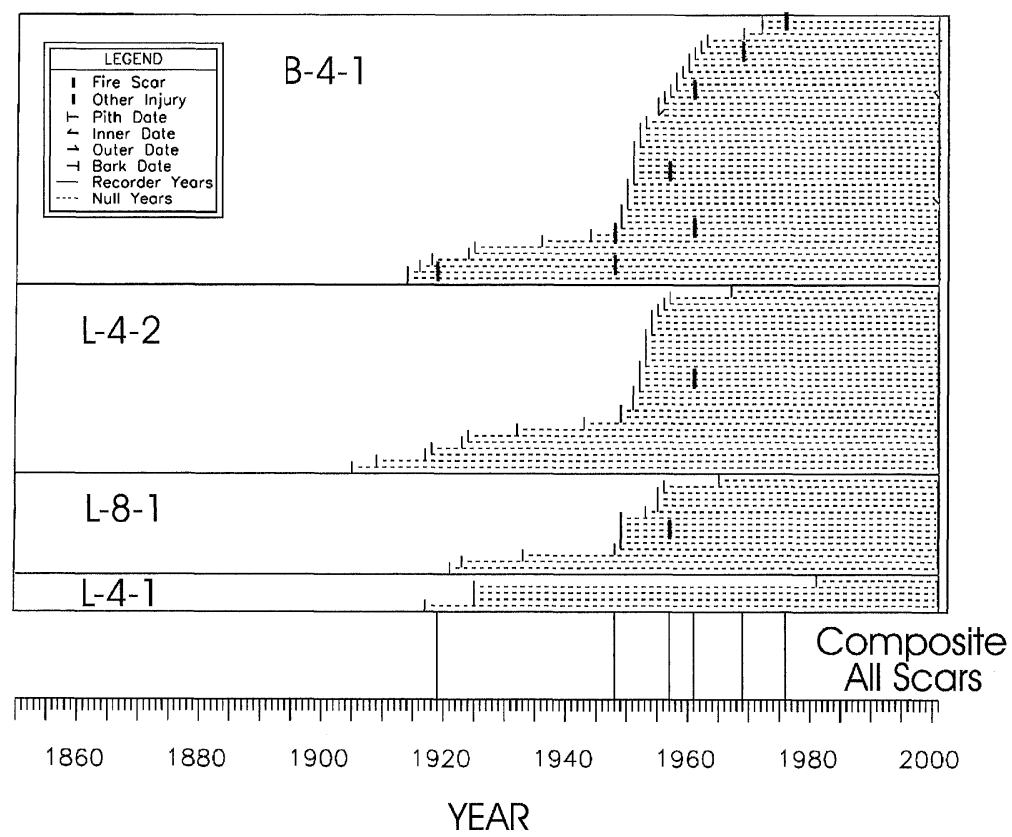

FIG. 2.- Tree age and composite fire history of the northern cluster in Monterey pine forests at Swanton Pacific Ranch, California. Each horizontal line is a tree and the pith date (far left vertical line) and fire scars (dark vertical lines) are identified. Opening label given in upper left of each segment 


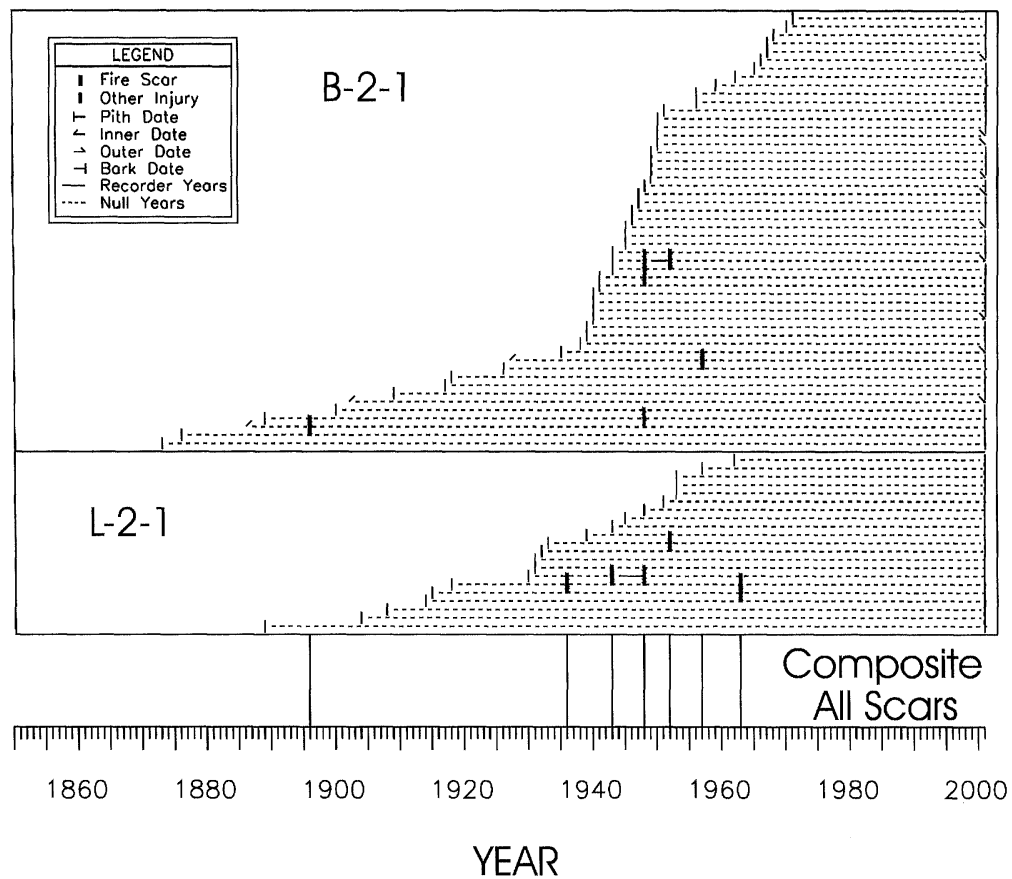

FIG. 3.-Tree age and composite fire history of the middle cluster in Monterey pine forests at Swanton Pacific Ranch, California. Each horizontal line is a tree and the pith date (far left vertical line) and fire scars (dark vertical lines) are identified. Opening label given in upper left of each segment

is coincident with a reduction of fire-use in rangeland management throughout California (Biswell, 1989). Some low severity fires could have been missed in this study because of the relatively low number of fire scarred trees.

Most Monterey pines in this study were $40-60 \mathrm{y}$ old, corresponding to the occurrence of three mixed severity fires. All openings had trees that survived the mixed severity fires, none of the openings only contained trees from a single cohort (Table 4; Figs. 2-4). Monterey pine and coast live oak continued to recruit in most openings after all fires. Fifty-one percent of the Monterey pine trees in all openings regenerated within $5 \mathrm{y}$ of three mixed severity fires. This is below the predicted value of $75 \%$ that was based on the literature (Vogl et al., 1988; McDonald and Laacke, 1990) and life history characteristic (Fonda et al., 1998; Fonda, 2001) of this species.

The 1948 fire produced the largest Monterey pine regeneration episodes in the northern and middle clusters (Table 4; Figs. 2-3). This fire was the Pine Mountain Fire that ignited on 31 August 1948 (Santa Cruz Sentinel News, 5 September 1948) and burned 6400 ha of forests, shrublands and grasslands over a period of $7 \mathrm{~d}$. It was the largest wildfire in Santa Cruz County in 12 y and was spread by strong northwest winds and low humidities. Aggressive fire suppression was unsuccessful in controlling this fire until it moved out of the forests and into less hazardous grasslands and shrublands.

The 1948 Monterey pine regeneration episode is absent in the southern cluster (Table 3; Fig. 4). The dendrochronolgy-based record depicts the 1948 fire as mixed severity and 


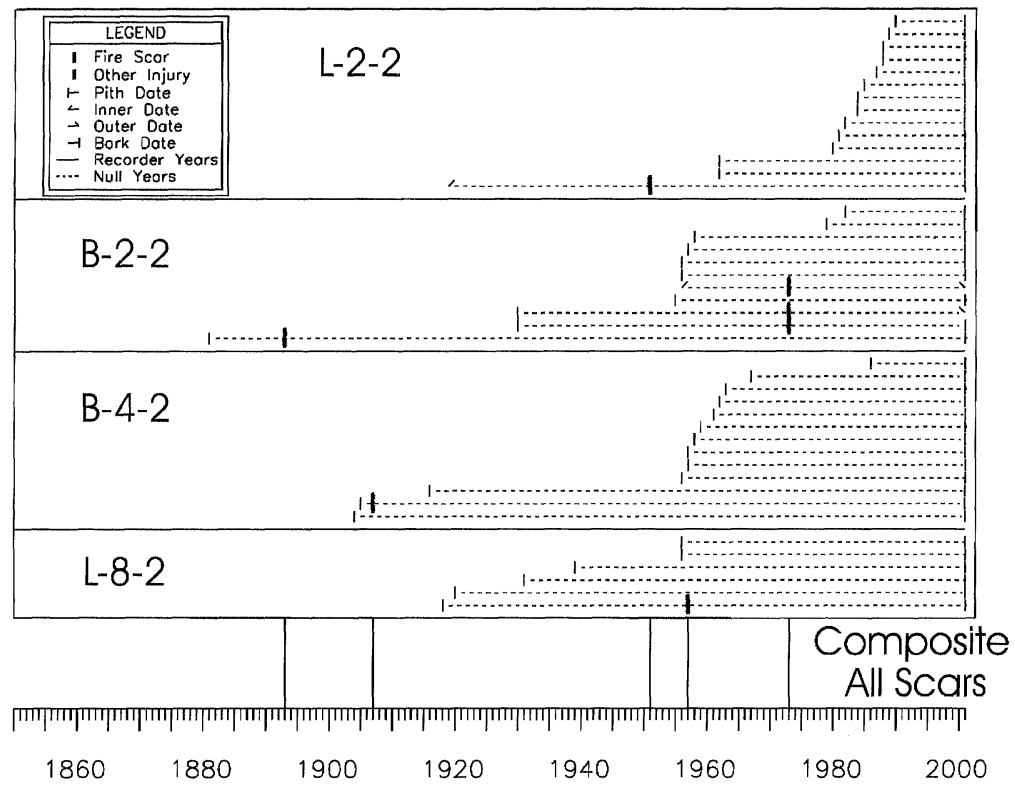

YEAR

FIG. 4.-Tree age and composite fire history of the southern cluster in Monterey pine forests at Swanton Pacific Ranch, California. Each horizontal line is a tree and the pith date (far left vertical line) and fire scars (dark vertical lines) are identified. Opening label given in upper left of each segment

eyewitnesses documented this behavior “... many areas were destroyed but in other parts of the burned area, some bushes and trees escaped the flames" (Santa Cruz Sentinel News, 6 September 1948). The written and tree-ring record are in agreement on the 1948 fire.

Historical accounts record that two other large wildfires occurred in northern Santa Cruz County in the 20th Century (Santa Cruz Sentinel News, 7 September 1948). The first was in September 1919 and burned an area similar to that burned by the 1948 Pine Mountain Fire. The second was a 10,400 ha wildfire that burned in 1936. Both of these fires are recorded in this study. The 1919 fire was recorded in the northern cluster and the 1936 fire is recorded in the middle cluster (Figs. 2, 3).

Regeneration in the southern cluster occurred only after a 1957 mixed severity fire, a fire also recorded by fire scars in the northern and middle clusters without a corresponding episode of regeneration (Figs. 2-4). Conversely, we did not record the 1936 or 1948 fires the southern cluster. The three mixed severity fires that burned in the study area had diverse behaviors and effects over a relatively small spatial scale $(800 \mathrm{~m}$ separate the northern and southern clusters). The Monterey pine forests sampled in this study were multi-aged (O'Hara, 1998; Valkonen, pers. comm., 2004) and had a great amount of spatial heterogeneity, attributes common in mixed severity fire regimes (Agee, 1998).

Monterey pine produces thick bark (McDonald and Laacke, 1990) and this is a characteristic of fire resistors (Fonda et al., 1998; Fonda, 2001). Thick bark enables trees to survive surface and ground fires because it insulates the cambium layer from lethal 
temperatures during combustion. Monterey pine has characteristics of both fire evaders (canopy stored seed-back, episodic regeneration) and fire resistors (ability to survive repeated low severity fires) and may be more appropriately classified in an intermediate category. Monterey pine could be classified as a fire tolerater because it can succeed when exposed to diverse fire severities.

As we predicted, regeneration of Monterey pine was significantly higher than coast live oak following mixed severity fires (Table 5). The autecology of Monterey pine allows it to take advantage of the environment created by mixed severity fires. Coast live oak can survive $100 \%$ crown scorch by producing epicormic sprouts from dormant buds (Plumb, 1980; Plumb and McDonald, 1981), but it cannot shield its propagules from lethal temperatures created by high severity fires.

Acknowledgments. -We thank David Yun for the GIS work on this project. Lud McCrary assisted us in documenting the written fire history information for the Swanton area. We thank Elicia Wise, Brandon Collins, Danny Fry, Nikolai Barca-Hall, Wally Mark, Robert Briggs and Ryan Hilburn for field and lab assistance. We thank Kevin O'Hara for reviewing this manuscript. This project was supported by funds from the University of California Berkeley Agricultural Experiment Station, California Department of Forestry and Fire Protection and Agricultural Research Initiative from Cal Poly State University.

\section{Literature Cited}

AGEE, J. K. 1998. The landscape ecology of western forest fire regimes. Northwest Sci., 72:24-34.

Ahlstrand, G. M. 1980. Fire history of a mixed conifer forest in Guadalupe Mountains National Park, p. 4-7. In: M. A. Stokes and J. H. Dieterich (eds.). Proc. fire history workshop. US For. Serv. Gen. Tech. Rep. RM-81.

BAKER, F. S. 1949. A revised tolerance table. J. For, 47:179-181.

Biswell, H. H. 1989. Prescribed burning in California wildland vegetation management. UC Press, Berkeley, California. 255 p.

Bowman, R. H. And D. C. Estrada. 1980. Soil survey of Santa Cruz County, California. US Dept. of Agric. Soil Conserv. Serv., Washington, D.C. 148 p.

Burdon, R. D., A. Firth, C. B. Low and M. A. Miller. 1997. Native provenances of Pinus radiata in New Zealand: performances and potential. New Zealand For., 41:32-36.

- R. A. BRITTON AND G. B. WALFORD. 2001. Wood stiffness and bending strength in relation to density of four native provenances of Pinus radiata. New Zealand J. For. Sci., 31:130-146.

Caprio, A. C. ANd T. W. Swetnam. 1995. Historic fire regimes along an elevational gradient on the west slope of the Sierra Nevada, California, p. 8-14. In: J. K. Brown, R. W. Mutch, C. W. Spoon and R. H. Wakimoto (eds.). Proc. of symposium on fire in wilderness and park management. US For. Serv. Gen. Tech. Rep. INT-GTR-320.

Condit, R., S. P. Hubbell and R. B. Foster. 1995. Mortality rates of 205 neotropical tree and shrub species and the impact of a severe drought. Ecol. Monogr. 65:419-439.

CRAWLY, M. J. 2002. Statistical computing, an introduction to data analysis using S-Plus. John Wiley and Sons, West Sussex, England. $761 \mathrm{p}$.

CREMER, K. W. 1992. Relations between reproductive growth and vegetative growth of Pinus radiata. For. Ecol. Man., 52:179-199.

Dieterich, J. H. and T. W. Swetnam. 1984. Dendrochronology of a fire-scarred ponderosa pine. For. Sci., 30:238-247.

Fenton, G. R. 1951. Regeneration of Pinus radiata. Forest research notes. New Zealand Forest Service Forest Research Institute, 1:1-14.

FonDA, R. W. 2001. Burning characteristics of needles from eight pine species. For. Sci., 47:390-396.

- L. A. Belanger and L. L. Burley. 1998. Burning characteristics of western conifer needles. Northwest Sci., 72:1-9.

Gordon, T. R., K. R. Wikler, S. L. Clark, D. Okamoto, A. J. Storer and P. Bonello. 1998. Resistance 
to pitch canker disease, caused by Fusarium subglutinans $\mathrm{f}$. sp. pini, in Monterey pine (Pinus radiata). Plant Path., 47:706-711.

Greenlee, J. M. and J. H. Langenhein. 1990. Historic fire regimes and their relation to vegetation patterns in the Monterey Bay Area of California. Am. Midl. Nat., 124:239-253.

Grissino-MAYER, H. D. 2001. FHX2-software for analyzing temporal and spatial patterns in fire regimes from tree rings. Tree-ring Research., 57:115-124.

McBride, J. R. 1983. Analysis of tree rings and fire scars to establish fire history. Tree-ring Bull., 43:51-67.

McDonald, P. M. And R. J. LaAcke. 1990. Pinus radiata, p. 433-441. In: R. M. Burns and B. H. Honkala (tech. coord.). Silvics of North America, Vol. 1. Conifers. US For. Ser. Agricultural Handbook 654.

Millar, C. I. 1999. Evolution and biogeography of Pinus radiata, with a proposed revision of its quaternary history. New Zealand J. For. Sci., 29:335-365.

O'HARA, K. L. 1998. Silviculture for structural diversity: a new look at multiaged systems. J. For., 96:4-10.

Old, K. M., W. J. LibBy, J. H. Russell And K. G. Eldridge. 1986. Genetic variability in susceptibility to Pinus radiata to western gall rust. Silvae Genetica, 35:145-149.

Plumb, T. R. 1980. Response of oaks to fire. In: Proc. of the symposium on the ecology, management, and utilization of California oaks. US For. Serv. Gen. Tech. Rep. PSW-GTR-44. AND P. M. MCDOnAld. 1981. Oak management in California. US For. Serv. Gen. Tech. Rep. PSWGTR-54.

REYES, O. AND M. CASAL. 2001. The influence of seed age on germination response to the effects of fire in Pinus pinaster, Pinus radiata, and Eucalyptus globulus. Annals of Forest Science, 58:439-447.

Shelbourne, C. J., R. D. Burdon, M. H. Bannister and I. J. Thulin. 1979. Choosing the best provenances of radiata pine, Pinus radiata, for different sites in New Zealand. New Zealand J. For., 24:288-300.

STEPHENS, S. L. 2001. Fire history of adjacent Jeffrey pine and upper montane forests in the Eastern Sierra Nevada. Inter. J. of Wildland Fire, 10:161-176.

Stokes, M. A. And T. L. Smiley. 1977. An introduction to tree-ring dating. University of Chicago Press, Chicago, Illinois.

Storer, A. J. AND D. L. Wood. 1998. Association between a native spittlebug (Homoptera: Cercopidae) on Monterey pine and an introduced tree pathogen which causes pitch canker disease. Canadian Entom., 130:783-792.

Swetnam, T. W., M. A. Thompson and E. K. Sutherland. 1985. Spruce budworm handbook, using dendrochronology to measure radial growth of defoliated trees. US For. Serv. Agriculture Handbook 639.

Turner, M. G., W. W. Hargrove, R. H. Gardner and W. H. Romme. 1994. Effects of fire on landscape heterogeneity in Yellowstone National Park, Wyoming. J. Veg. Sci., 5:731-742.

-, W. H. Romme, R. H. Gardner and W. W. Hargrove. 1997. Effects of fire size and pattern on early succession in Yellowstone National Park. Ecol. Monogr., 67:411-433.

Vogl, R. J., W. P. Armstrong, K. L. White and K. L. Cole. 1988. The closed-cone pines and cypress, p. 295-358. In: M. G. Barbour and J. Majors (eds.). Terrestrial vegetation of California. Wiley and Sons, New York.

White, K. L. 1999. Revisiting native Pinus radiata forests after twenty-five years. Madrono, 46:80-87. 